\title{
Learning Management Systems in Academic and Corporate Distance Education
}

\author{
https://doi.org/10.3991/ijet.v16i11.20701 \\ Viktor Shurygin $(\bowtie)$ \\ Kazan Federal University, Elabuga Institute (Branch), Elabuga, \\ Russian Federation \\ viktor_shurygin@mail.ru \\ Natalya Saenko \\ Moscow Polytechnic University, Moscow, Russian Federation \\ Angelina Zekiy \\ Sechenov First Moscow State Medical University, Moscow, \\ Russian Federation \\ Elena Klochko \\ Kuban State Agrarian University named after I.T. Trubilin, Krasnodar, \\ Russian Federation \\ Mikhail Kulapov \\ Plekhanov Russian University of Economics, Moscow, Russian Federation
}

\begin{abstract}
Present-day development of information technologies is making deeper and deeper incursions into all spheres of human activity, both social and economic. It is only natural that they greatly influence the educational industry, changing the approaches, methods and forms of education. Currently e-learning and distance technologies are being actively introduced into both academic and corporate education, as complementary to traditional forms. The efforts of teachers are aimed at finding effective models of blended learning. All this determines the relevance of the present study. The abstracted article is aimed at developing frameworks of a distance learning model based on the use of modern learning management systems. To obtain thorough and reliable results the authors make use of two research approaches: acmeological and competencebased. They review the features, the scope and use of the existing LMS platforms and work out tools for the development of e-learning system. In addition, they assess the compliance of e-learning tools with the preferences of $\mathrm{X}, \mathrm{Y}$ and $\mathrm{Z}$ generation users. The outcome of the research is the development of a universal competency that can be applied to the study of modern methods and approaches with reference to both academic teaching and learning, and to corporate training. It is quite apparent that pros and cons of the learning management system and its possibilities should be carefully studied and thoughtfully used. The effective e-learning requires constant monitoring of equipment, proper work of host servers and considering user-friendliness of the platforms. This is related to the fact that public educational organizations, including schools, col-
\end{abstract}




\begin{abstract}
leges and universities, especially in low developed countries, prefer traditional teaching methods and are slowly moving to innovative models. The research findings can be viewed as a step forward in creating user-friendly and flexible e-learning platforms, suitable for separate users, institutions and businesses. They can be applied for further assessment of existing learning models, especially for the younger generation, and for research and development of new strategies and methods of using learning management systems and platforms.
\end{abstract}

Keywords - Educational methods, LMS-models and systems, on-line educational platforms

\title{
1 Introduction
}

Advances in information and cognitive technologies are changing the pace and the face of social and business processes today. Certainly, the flourishing industry of technology is influencing both the general and corporate subsectors of education sector, resulting in a change of teaching approaches, modes and methods. The use of diverse gadgets in e-learning helps speed up the learning process and create a convenient flexible schedule for students and employees. Education in an online environment is famous for its interactivity and opportunities to combine several teachings and learning strategies. In addition, e-learning courses are normally designed for individuals who are both advanced and new to the subject matter $[2 ; 11 ; 25 ; 28 ; 53]$.

Recently, the Learning Management System (LMS) has been at the forefront in education [71]. It is also known as an e-learning platform that enables the training process both online and offline. The top famous e-learning platforms include Moodle, Blackboard, Canvas, eCollege, Cornerstone, SumTotal, WebCT (now owned by Blackboard), and etc. Overall, the LMSs are classified into international (TalentLMS, LearnUpon, eFront) and local e-learning platforms (iSpring Learn, Mirapolis LMS, ShareKnowledge, Teachbase, and etc.) with the latter category taking into account the national demands for and trends in education $[10 ; 40 ; 6 ; 65 ; 37]$.

Most scholars interested in the modernization of learning systems pointed out that the use of e-learning platforms enabled institutions to teach hundreds and even thousands of students, employees and clients around the world at once. Surely, this type of technology can be used by diverse educational and business organizations. The software platform offers functionality to manage and track the activity of all parties involved in the learning process, i.e., learners and teachers [17; 32; 12; 43].

Educational institutions use e-learning platforms for multiple reasons. The LMS technology helps enroll students who do not live near or within the campus location. Usage of teaching technologies is not limited to the audience size. In addition, students and remote learners have the opportunity to study at a time and a pace that is most convenient for them. Also, they have additional opportunities to use tactical strategies for integrating various teaching methods into managed modules or smaller lesson units $[51 ; 41 ; 48]$.

Business organizations, on the other hand, use LMSs to make sure that new and old employees have the necessary skills and competencies. These organizations can also 
use this type of technology to convey company rules and other valuable information (e.g., safety rules) to recruits [70]. Organizations have also perceived that their training platforms can be used as a tool for continuous learning improvement beyond compatibility and adaptability $[77 ; 89 ; 86]$. New technologies such as the e-learning platforms require potential users to create new curricula. Eventually, the mainstream trends in education will demand the improvement of a regulatory framework for this industry.

Hence, the research questions are:

1. What distinguishes LMS platforms applied in educational institutions and private corporations?

2. What are the strengths and weaknesses of LMS platforms?

3. What opportunities do LMS platforms provide?

4. What are the modern concepts of distance learning?

5. What distance learning platforms are used to teach younger generations $(\mathrm{X}, \mathrm{Y}$, and $\mathrm{Z})$ ?

6. What are the reasons younger generations prefer to use remote learning platforms than traditional teaching methods?

7. What are the conceptual fundamentals of distance learning that may be utilized in Human Resource strategies?

\section{Literature Review}

In today's dynamically changing world, the latest technology may become obsolete in a few years or decades [56; 79]. The knowledge students acquire in school and university may no longer be of value by the time of employment [13]. This makes the LMS platforms market one of the fastest growing markets in the technology industry [18]. The educational LMS space integrates the breakthrough technologies like artificial intelligence, virtual reality, and mobile communications to attract more platform users [27]. In recent years, there has been an active promotion of LMSs in higher education $[26 ; 21]$ The technology market offered new tools for the higher educational institutions to manage their e-learning process. Most teachers and administrators' value LMS benefits such as the ability to better make course content, track, and report student progress [47]. The relevant concerns of LMS designers and providers relate to meeting the needs and preferences of young generations (i.e., X, Y, and Z). The representatives of these generations view mobile training as a necessity and the Gen $\mathrm{Z}$ usually encourages organizations to improve their infrastructure by digitalization [58]. In this light, the system of higher education needs to be redefined in terms of mobile communications. The key additions involve:

1. Content library with searchable video materials

2. Collaborative learning solutions

3. Content quality control mechanisms

4. Solutions for self-study and critical thinking $[54 ; 55]$. 
The LMS applications have existed almost for two decades [80]. Recently, they have gained popularity among private colleges and universities due to the rise of the global Internet $[9 ; 15]$. The growing number of these institutions not only gave rise for the education quality concerns but also opened new opportunities [16].

Initially, e-learning platforms were used to document and conduct online, asynchronous, and computer-based training via the Internet. Nowadays, a learner can also use these platforms for streaming or synchronous study. The LMS analytical reports help individuals and training organizations perform better $[83 ; 34 ; 36]$.

Although the LMS software solutions may be used by any institution, either a private training organization or a business entity [81], particular platforms are designed to meet the needs of specific organizations [41]. This contradiction arises from the fact that teaching strategies used by business companies differ from those typically implemented in higher education. In addition, LMS platforms offer a set of tools to track e-learning performance and get certification $[15 ; 17 ; 76]$.

Sources analyzed within the framework of this study stipulate that the diversity of approaches towards the e-learning course design is linked to the contexts of e-learning such as technology infrastructure, limitations of the discipline and curricula, and stakeholders [68]. As many users have pointed out, learning through LMS (e.g., Moodle platform) is fraught with difficulties such as user-unfriendliness, server requirements, and substantial skills requirement. Since user-unfriendliness is the most common complaint relating to Moodle, many measures have been recently taken to simplify its workplace [78; 84].

Hence, when implementing an e-learning solution, it is necessary to monitor hardware health and software performance, to keep the hosting servers in function, and to improve the system's functionality for the convenience of users (students). In addition, the state educational institutions, especially in less developed countries with medium and low incomes, prefer traditional teaching methods and move towards an innovative classroom at a slow pace $[72 ; 73 ; 6]$.

\section{$3 \quad$ Materials and Methods}

\subsection{Research design}

The LMS design is intended to create a user-convenient learning experience. In particular, e-learning software solutions allow users (students, teachers, administrators) to generate e-learning content (lessons), organize it into courses, deliver the content, enroll students to said courses, and, finally, to monitor and assess their performance.

Methods used in the study to explored the quantitative and qualitative changes in the LMS market in China and around the world include general research methods and methods of statistical, economic and financial analysis. The design and use of foreign and Russian LMS platforms were analyzed by means of a comparative approach. Through systematization and theoretical generalization, a set of e-learning manage- 
ment tools was developed. In addition, the study explored the extent to which elearning tools meet the preferences of potential multi-generation users.

Findings obtained using the acmeological and competency-based approaches as well as by modeling allowed building an underlying model of e-learning management based on the principles of technocracy [22]. This LMS model illustrated the process of LMS integration in higher education.

At its core, a learning management system is a software application that helps create, manage and deliver e-learning courses. An LMS is an "engine" that powers elearning. In the most common form, it consists of: (1) a server component that performs the core functionality (creating, managing and delivering courses, authenticating users, serving data and notifications, etc.); and (2) a user interface that runs inside a browser as a web (like Gmail or Facebook) that is used by administrators, instructors and students.

A non-exhaustive list of LMS users includes anybody, who is engaged in elearning; businesses of all sizes; for-profit and non-profit organizations; government agencies and local governments; and educational institutions, from traditional to online and e-learning-based (e.g., online schools from Khan Academy to Lynda.com).

An LMS can be used as a virtual classroom tool to teach both university students and employees across the globe. Its pros include (1) the availability of learning materials (books, videos, e-courses, tests, and etc.); (2) the ability to study at distance; (3) the ability to create a streamlined onboarding process; (4) detailed statistics for keeping track of the progress of learners or departments. For each course, the said statistics involve the total number of currently open courses, test scores, the relative learning path, and so on [25].

The LMS types are divided in two categories: housed on a computer (on premise or self-hosted) and cloud-based (hosted online). Here are some of the most common use cases for an LMS platform. With LMS, companies can cut down on employee training costs and eliminate business disruptions associated with traditional learning by letting their employees study materials online and at their own pace. It is also a good place to educate new hires on the company's employee conduct code, privacy guidelines, and policies. LMS is a good fit for the needs of online course sellers, educational organizations seeking to supplement their classroom-based courses, businesses, and even government or non-government agencies [57].

\subsection{Data analysis}

The implementation of e-learning through LMS is governed by the latest information technology trends [44]. Thus, the e-learning content must meet the requirements imposed by a digital society. According to the IDC's "third platform" concept, the LMS platforms must integrate with mobile devices and cloud systems, permit big data analytics, and be a social technology. In 2019, a shift towards cloud computing continued at the accelerating pace. Hence, one may suggest that the present-day society is aware of a growth-driving role of the IT industry [57;63].

Over the past three years, GfK reports have been acknowledging a mobile internetuser boom. The statistic showed the audience of Internet users in Russia has hit a 
high. By the end of 2016, the total number of Internet users did not change significantly, while the number of users accessing the Internet from mobile devices amounted to 8.5 million people by the end of 2018 [70]. In addition, the ICT-based distance learning opportunities are constantly expanding. Thus, according to the 2017-2030 Strategy for the Development of an Information Society in the Russian Federation, elearning solutions are expected to help expand the availability of high-quality educational services. Many institutions of higher education in Russia apply LMS to streamline the distance learning process [75].

Figures 1-3 show the number of users of the world's most popular LMS platforms from the 2018 Capterra report. The market analysis embraced two sub-segments, academic and corporate LMS.

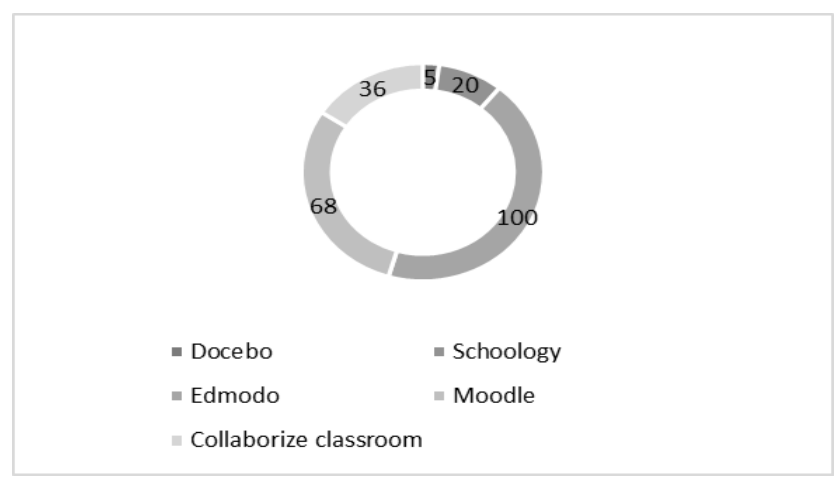

Fig. 1. The top 5 most popular LMS-platforms by total customers (in thousand), 2018

Source: [47]

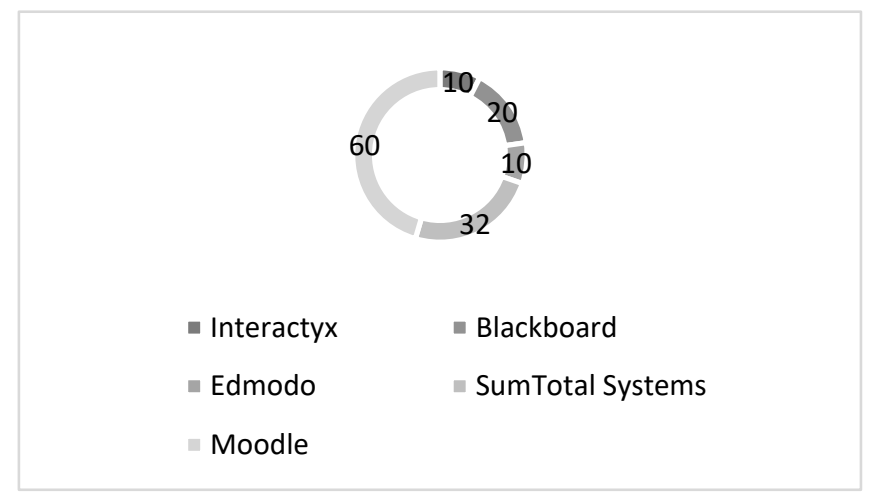

Fig. 2. The top 5 most popular LMS-platforms by total users (in thousand), 2018

Source: [47]

Recent years saw a number of technology advances but the considerable change in the market was linked to customer expectations. Today, it is not enough to offer a piece of software; people want solutions. 
At the rate the extent of learning management system research and development initiatives is driving new technological innovations [69; 87], it is probable that many companies will invest more of their L\&D dollars into a learning management system, which not only delivers and tracks training but also provides effective results. The same goes for schools worldwide, where administrators are increasingly collaborating with their IT departments in choosing the best LMS for their institutions [8; 62].

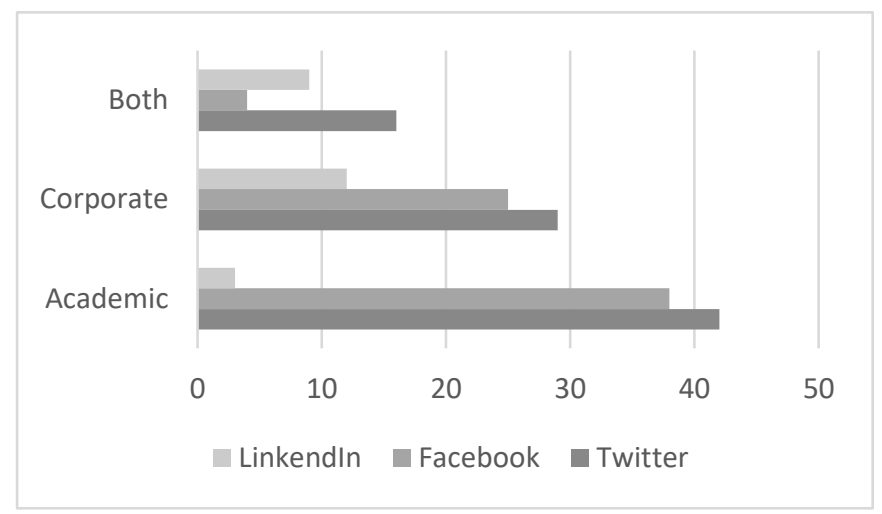

Fig. 3. LMS market by target segments (corporate, academic) (in thousand), 2018

Source: [47]

For the past 16 years, small businesses have increased their use of e-learning by $900 \%$, making online learning as the new normal (SmallBizTrends). Among businesses that use LMS systems, 74\% of employees take advantage of the BYOD policy (bring-your-own-device policy that regulates IT department's level of support for employee-owned devices) as this enables learning at the comfort of their own device (Tech Pro Research). As adults spend up to five hours daily watching videos, $98 \%$ of organizations worldwide are using video-based training programs in their digital learning approaches (Ambient Insight). Among college students who had the option to choose between online and traditional face-to-face learning, almost $60 \%$ selected online learning (Learning House and Aslanian Market Research). By 2020, 98\% of small business are planning to use LMS to fulfill their learning requirements (SmallBizTrends). To fill-up their skills gaps and reach their full capacity, numerous companies have invested more money into L\&D in 2018 (Forbes). The overwhelming majority of students use mobile devices not only to search for their online program of study $(87 \%)$ but also to complete online coursework $(67 \%)$ (Learning House and Aslanian Market Research). Taking advantage of LMS platforms offerings, Google has enrolled 80,000 of its employees in Udacity's HTML5 course [27].

At the end of 2017, the Stanford University and the Stanford Graduate School of Business finished their transitioning to Canvas, a cloud-based learning management system developed by Instructure, Inc. (LMS) [14]. Stanford had used CourseWork (Sakai) LMS since 2005. Over the last ten years, there have been many changes in the LMS technology. Modern learning management systems offered exciting features and 
functionalities. Therefore, Stanford selected Canvas as its new LMS after a review of a current LMS landscape and the analysis of feedback from the Canvas pilot [12]. The Canvas team claims that currently $48 \%$ of campuses worldwide consider to migrate to another LMS. The Canvas project was launched in 2011. It is a flexible, secure, and adaptable LMS that supports current and evolving teaching and learning needs. Canvas can be implemented to organize a course using content modules as well as to stimulate active learning and critical thinking. Among other benefits, the Canvas LMS features an easy creation of learning content, permits file attachments, and allows the instructor and students to communicate using text and video (via webcam). The Canvas tool enables the creation of group projects. Instructure also offers a mobile app for smartphones [5].

Today, millions of people around the world and over 3,000 educational institutions use Canvas. Among them, the University of Pennsylvania, the Northwestern University, and the Columbia Business School. As of 2018, Stanford made more than 1,780 courses with Canvas [12].

Another example of LMS is the Cambridge Learning Management System (CLMS), a robust platform that holds course content, materials and administration in one user-friendly online system. This platform allows teachers to easily manage classes and track their students' progress by highlighting areas of strength and weakness for ongoing performance improvement [19]. What is more, CLMS creates an environment where students can interact with content, collaborate with other learners, and communicate with their teacher outside the classroom. Through using the CLMS over 37 weeks, Anadolu University in Turkey saw a $1418 \%$ increase in student participation by the end of 2018 .

Students and instructors may use CLMS to: (1) spend more time teaching/improving one's learning performance outside the classroom; (2) facilitate personto-person communication and encourage the interaction with tools such as forums and blogs. These helps improve communication skills and create a learning environment that is more engaging; (3) improve course organization and reduce administration; (4) with a range of automatic marking and reporting tools, to quickly and easily track and comment on students' progress. This leaves more time for teachers to concentrate on teaching $[10 ; 25]$.

The St. Petersburg State University of Economics (UNECON) makes use of the Russian Moodle 3KL. The majority of training courses offered by the Department of Computer Science were created in Moodle and hosted by the university. LMS cannot replace face-to-face learning, but it is able to supplement the teaching and learning process.

As of now, there are 5 e-learning platforms dominating the Russian market:

iSpring Online is a corporate training platform with a powerful easy-to-use authoring tool. This platform differs from other digital solutions in features. It has an unlimited cloud storage. Users can upload webinars and create step-by-step learning pathways. The platform streamlines the assessment process, the instructor just uploads an electronic course (all quizzes in one presentation) and invites students. The platform gathers detailed progress statistics and engages users through gamification. In addition, iSpring publishes courses to various formats [50]. 
WebTutor is a solution by WebSoft for large companies with many employees such as Rosgosstrakh, Danone, M.Video, Lukoil, Svyaznoy, and Garant. WebTutor allows brining many departments or branches together in a network; streamlining the certification process; making reports; tracking progress; exchanging information with other users via chats, forums, blogs and more [61].

Mirapolis LMS is a program designed to automate the Human Resource processes by integrating multiple systems. The platform is favored by large companies such as Gazprom, Sberbank, Rosatom, Russian Railways, Mail.ru, and etc. The platform has an unlimited knowledge database and multi-level development programs. The Mirapolis Virtual Room allows webinar recording. Overall, the app offers four learning modes: full-time, part-time, distance and blended [31].

Teachbase is a cloud LMS, which allows companies to teach their employees, partners and clients [1] but only registered users can benefit from its functionality. The platform has an authoring tool and allows users to upload PPT and PDF files, video content, and MS Office files.

Moodle is the world's most widely used LMS. This system is an open-source software application, which means that programmers can produce their own add-ins and useful extensions. Thus, the platform has plugins that enable the storage of information in a multi-level folder structure. Moodle ensures communication and collaboration (via blogs, forums, glossaries, workshops, and chats); allows tracking the learner's frequency of the LMS use and the duration of stay on the LMS; and permits portfolio attachment [66].

To sum up, the above e-learning platforms have pros and cons. The LMS's ease-ofuse depends on how well the platform is adapted to the user's needs [57].

\section{$4 \quad$ Results}

Figure 4 below is a summary of the underlying concepts, approaches, models and principles associated with e-learning. As it can be seen, only two approaches were selected from among the existing methods, acmeological, and competence-based. The acmeological and competence-based research approach methods contribute to the identification of learners' character traits, values, life principles, abilities, and competencies [49; 42].

The key principles embraced by the model are (1) democracy (this refers to freedom and global-level integration in all spheres of life, including education); (2) technocracy (i.e., the use of technologies by society); and (3) robokratism. There is an opinion that a new class of society will form in the near future such as Robokrats, specialists in the field of information technologies and programmers. Today, these people are involved in technological and economic business management. By analytical forecasts, they may take a leading role in the society of the future.

Distance education implies the use of (1) digital learning tools (e.g., specialized and personalized electronic courses, master-classes, collaboration tools, and etc.); (2) different forms of learning process organization (i.e., education programs, cycles, practice-based learning; more detailed in Figure 2); and (3) LMS platforms [67]. 
Unlike the existing models of e-learning system management, the LSM model offered here takes into account the contemporary tendencies in the teaching and learning process organization, the projections of future education, and the needs of potential employers.

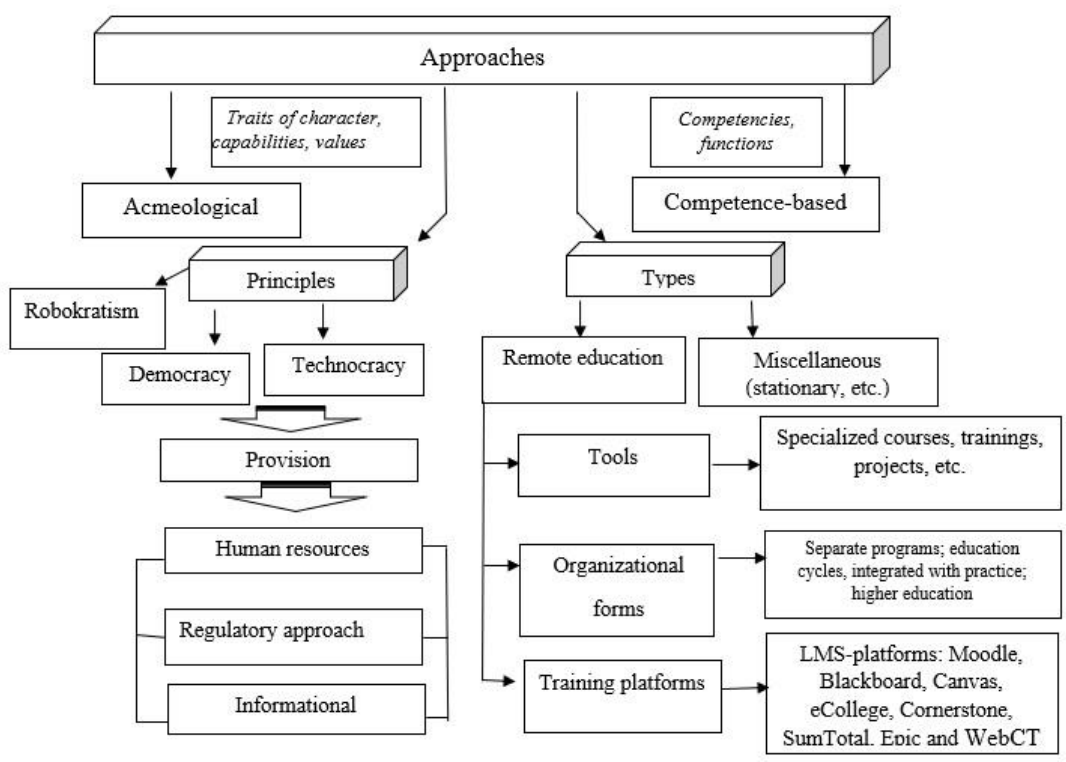

Fig. 4. The underlying model of e-learning management (created by the author)

The present management system is best implemented with respect to young generations (i.e., X, Y and Z), as they are able to adapt and perceive large amounts of information daily.

Figure 5 offers a list of tools for e-learning improvement desired by high-potential candidates of generations $\mathrm{X}, \mathrm{Y}$, and $\mathrm{Z}$.

The range of preferred means constitutes teaching methods other than those implemented in a full-time class setting such as the oral presentation of material using lectures and classroom-based courses. Modern-day learners adhere to practiceoriented and engaging approaches like context-based learning, workshops, e-learning, cross-border learning, challenge-based learning, and etc. Through an interactive learning framework, learners with high expectations acquire the opportunity to gather new experience, learn foreign languages, and travel [29]. In addition, the best experience of in-company education suggests the collaborative project-based learning approach to be an effective means of teaching [85].

As mentioned earlier, many organizations focus on increasing their revenue growth rates by recruiting high-potential employees [20]. Thus, according to the Global Leadership Forecast 2018 survey, only $14 \%$ of respondent companies work to reach a strong/high-potential leadership bench, while the remaining companies are more like- 
ly to have a passive attitude towards the identification of a high-potential talent [32]. Today, the global business community feels the need for identifying high-potential employees, who may have a leadership talent developed before employment, e.g., during the learning period or when participating in a family business and international projects [23].

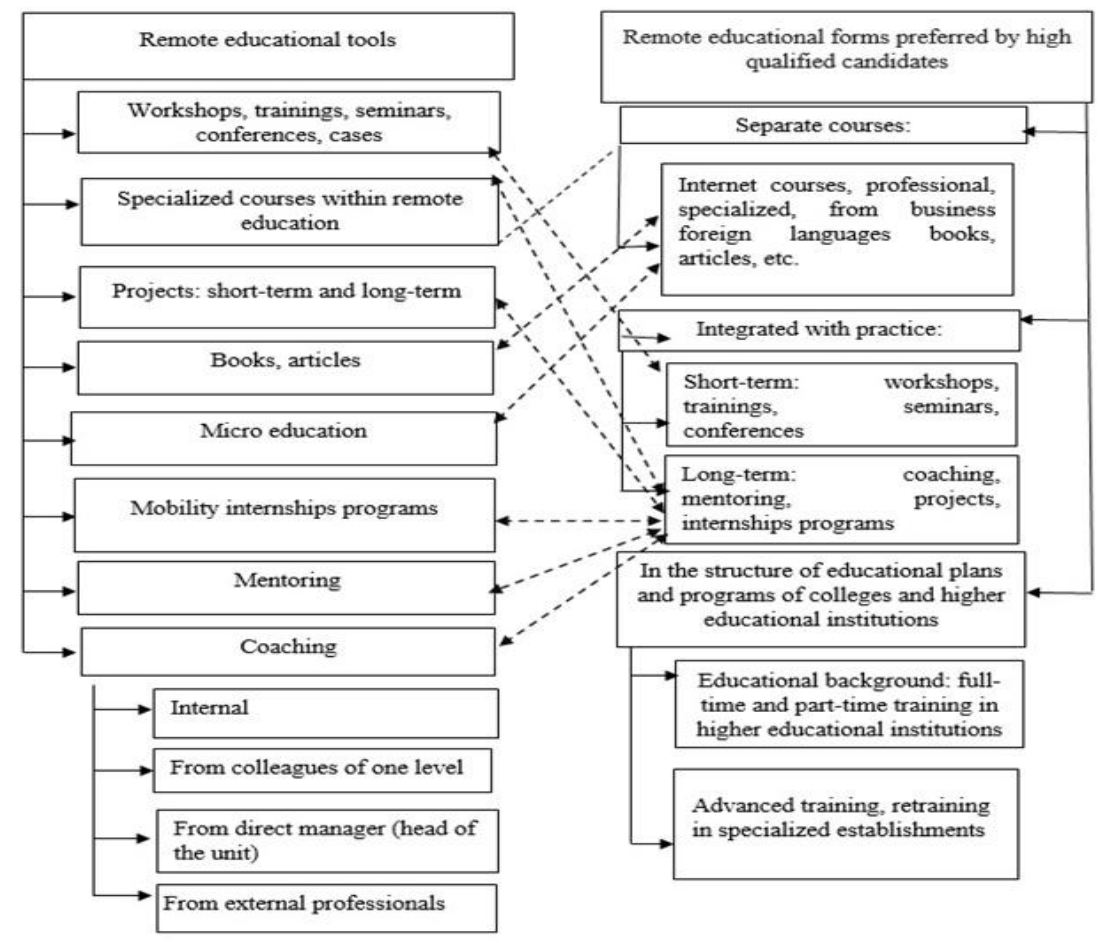

Fig. 5. E-learning development tools desired by young generations, $\mathrm{X}, \mathrm{Y}$, and $\mathrm{Z}$ (created by the author)

Generally, the education-related issues discussed in this study underlie the current need for maintaining the existing and forming the new HR skills in employees [45]. The overwhelming majority of high-potential specialists prefer to embark on personalized learning paths. However, many companies do not prioritize this learning approach, and therefore, investing in education may not give an expected result.

\section{Discussion}

With e-learning at the forefront of education, many studies have recently appeared that examine the effectiveness of education in a digital setting [74; 4]. These works offer intriguing conclusions about what makes e-learning effective and may help instructors plan the learning journey of a target audience [3]. For instance, the diversity 
of e-learning approaches complicates the education quality assessment, especially in the context of informatization [24]. The solution to this problem involves developing a universal method for the evaluation of technology effectiveness. In the long run, users will be able to make learning more productive by choosing an e-learning solution based on its effectiveness and user-friendliness scores [59; 83; 41]. This is especially relevant given the diversity of LMS functionality $[35 ; 34 ; 36]$. Sometimes applications have a complex interface design, which requires IT skills and up to several months of free time to handle it [30]. Some software applications have a high price label, while others, sold at a lower price or free, lack a good authoring tool and have a limited range of authoring features [7]. Among other cons, authors emphasize occasional bugs and the lack of mobile apps that work without Internet access $[64 ; 88 ; 89]$.

In general, the scientific discourse concerned with the LMS-based education focuses on finding the most appealing and effective methods of teaching. One group of scientists is concerned with how the corporate LMS software should be designed to match each generation's preferred style of learning. They recommend modifying the curriculum to make it dynamic given the distinct preferences of millennial and Gen $\mathrm{Z}$ users $[33 ; 52]$. Scholars also draw attention to the fact that millennials and Gen $\mathrm{Z}$ users appreciate the opportunity to update their skills, flexibility and independence. Both generations are accustomed to seeking information and "how-to" videos on Google and YouTube. They have a desire to actively guide their own careers. This necessitates the creation of a completely independent approach to the delivery of education [38; 46]. Another group of scientists recommends to remember that a LMS design thinking process is not linear [60;82]. Evaluation and testing at any phase can send the process back to a previous step for refinement or to surface new ideas. As the business needs to scale and accommodate new demands, it is also crucial to correctly integrate the LMS-based learning solutions with the common L\&D strategy [39].

\section{Conclusion}

The present findings indicate that today's younger generations learn in a different way, through technology and by using electronic sources of information, rather than paper books and one's own experience. The analytics show that students most often prefer to study remotely and educational institutions satisfy the said preferences by blending full-time and distance learning courses together. Recently, the educational institutions have faced the need for assigning personalized learning plans. Meanwhile, the business organizations require their employees to complete the mandatory training online (e.g., via new hire training programs, safety and health training programs, language learning apps, webinars, and etc).

LMS, cloud-based and self-hosted, allows integrating different objects and services into its ecosystem in order for learners to receive learning experience anytime. According to the present research, the main advantages of LMS are the advanced tracking options, the ability to communicate via a discussion board and chats, and knowledge management tools. 
Findings show that the e-learning framework of education is more successful and popular among the representatives of new generations. In higher education, traditional classroom-based teaching supplemented by LMS platforms provides additional benefits and opportunities such as a set of extra courses that a leaner may take whenever convenient. As it can be seen, the approach towards teaching is changing. Not only IT and online technologies transform the system of education but they also integrate with the existing learning strategies and become integral to human development.

The study proposed a number of resources desired by high-potential representatives of young generations. These resources will help develop e-learning in higher education given requirements imposed by globalization. With this information, businesses will be able to improve their Human Resource strategies by incorporating elearning into their corporate training programs.

\section{$7 \quad$ References}

[1] Akhmetova, S., Nevskaya, L., \& Akhmetova, M. (2017). Social Learning of Company's Personnel by Means of Cloud Decisions. Montenegrin Journal of Economics, 13(1), 159169. https://doi.org/10.14254/1800-5845/2017.13-1.11

[2] Al-Hawari, F., \& Barham, H. (2019) A machine learning based help desk system for IT service management. Journal of King Saud University - Computer and Information Sciences. Retrieved from https://www.sciencedirect.com/science/article/pii/S1319157819300 515. https://doi.org/10.1016/j.jksuci.2019.04.001

[3] Anderson, R. C., Spiro, R. J., \& Montague, W. E. (2017). Schooling and the acquisition of knowledge. London: Routledge.

[4] Aparicio, M., Bacao, F., \& Oliveira, T. (2016). An e-learning theoretical framework. An elearning theoretical framework, 19(1), 292-307.

[5] Baldwin, S. J., \& Ching, Y. H. (2019). Online Course Design: A Review of the Canvas Course Evaluation Checklist. International Review of Research in Open and Distributed Learning, 20(3). https://doi.org/10.19173/irrodl.v20i3.4283

[6] Best LMS Software (2019) Reviews of the Most Popular Systems. Best LMS Software. Retrieved from https://www.capterra.com/learning-management-system-software/

[7] Black, E. W., Beck, D., Dawson, K., Jinks, S., \& DiPietro, M. (2007). Considering implementation and use in the adoption of an LMS in online and blended learning environments. TechTrends, 51(2), 35-53. https://doi.org/10.1007/s11528-007-0024-x

[8] Blau, I., \& Hameirie, M. (2010). Implementing technological change at schools: The impact of online communication with families on teacher interactions through learning management system. Interdisciplinary Journal of E-Learning and Learning Objects, 6(1), 245257. https://doi.org/10.28945/1313

[9] Boumarafi, B. (2010). Strategies for the delivery of e-information services to support the elearning environment at the University of Sharjah. The Electronic Library, 28(2), 276-285. https://doi.org/10.1108/02640471011033639

[10] Calvani, A., Fini, A., Molino, M., \& Ranieri, M. (2010). Visualizing and monitoring effective interactions in online collaborative groups. British Journal of Educational Technology, 41(2), 213-226. https://doi.org/10.1111/j.1467-8535.2008.00911.x

[11] Cantabella, M., Martínez-España, R., Ayuso, B., Yáñez, J. A., \& Muñoz, A. (2019). Analysis of student behavior in learning management systems through a Big Data framework. 
Future Generation Computer Systems, 90, 262-272. https://doi.org/10.1016/j.future.2018.0 $\underline{8.003}$

[12] Canvas - a VPTL resource (2019). Canvas - a VPTL resource. Canvas Resources \& News. Retrieved from: https://gocanvas.stanford.edu/

[13] Caplan, B. (2018). The case against education: Why the education system is a waste of time and money. Princeton: Princeton University Press. https://doi.org/10.37074/jalt.20 20.3.1.13

[14] Castillo-López, S. E., Guirao, S. K. F., Roldán-Reyes, E., Macias, A. A. M., \& Duque, D. M. (2019). A service design process based on the business model CANVAS and the CK theory. In Managing innovation in highly restrictive environments (pp. 279-301). Cham: Springer. https://doi.org/10.1007/978-3-319-93716-8 13

[15] Cavus, N., \& Alhih, M. S. (2014). Learning management systems use in science education. Procedia-Social and Behavioral Sciences, 143, 517-520. https://doi.org/10.1016/j.sbspro. 2014.07.429

[16] Chen, B., \& Yinb, H. (2018). Learning category distance metric for data clustering. Neurocomputing, 306(6), 160-170. https://doi.org/10.1016/j.neucom.2018.03.048

[17] Chow, J., Tse, A., \& Armatas, C. (2018). Comparing trained and untrained teachers on their use of LMS tools using the Rasch analysis. Computers \& Education, 123, 124-137. https://doi.org/10.1016/j.compedu.2018.04.009

[18] Davoli, F., Meyer, N., Pugliese, R., \& Zappatore, S. (2010). Remote Instrumentation and Virtual Laboratories. Springer Science+Business Media. https://doi.org/10.1007/978-14419-5597-5

[19] Dougiamas, M., \& Taylor, P. (2003). Moodle: Using learning communities to create an open source course management system. In EdMedia+ Innovate Learning (pp. 171-178). Waynesville: Association for the Advancement of Computing in Education (AACE).

[20] Downs, L. (2015). Star talent: Investing in high-potential employees for organizational success. Industrial and Commercial Training, 47(7), 349-355. https://doi.org/10.1108/ict06-2015-0041

[21] Dudukalov, E. V., Rodionova, N. D., Sivakova, Y. E., Vyugova, E., Cheryomushkina, I. V., \& Popkova, E. G. (2016). Global innovational networks: Sense and role in development of global economy. Contemporary Economics, 10(4), 299-310. https://doi.org/10.570 9/ce.1897-9254.217

[22] Dunlop, C. A., \& Radaelli, C. M. (2020). Technocracy and Public Policy. London: Routledge.

[23] Dries, N., \& Pepermans, R. (2008). "Real" high-potential careers. Personnel Review, 37(1), 85-108. doi: 10.1108/00483480810839987.

[24] Ehlers, U. D., \& Pawlowski, J. M. (2006). Quality in European e-learning: An introduction. In Handbook on quality and standardisation in e-learning (pp. 1-13). Berlin, Heidelberg: Springer. https://doi.org/10.1007/3-540-32788-6_1

[25] eLearning Industry (2019). Learning Management Systems (LMS) Articles. Retrieved from https://elearningindustry.com/subjects/elearning-software/learning-managementsystems-lms

[26] Fathema, N., Shannon, D., \& Ross, M. (2015). Expanding the Technology Acceptance Model (TAM) to examine faculty use of Learning Management Systems (LMSs) in higher education institutions. Journal of Online Learning \& Teaching, 11(2), 210-232.

[27] Financesonline.com. (2019). 25+ Essential LMS \& eLearning Statistics: 2019 Analysis of Trends, Data and Market Share. Retrieved from: https://financesonline.com/25-essentiallearning-management-system-e-learning-statistics-analysis-of-trends-data-and-market$\underline{\text { share/\#softwareadoption }}$ 
[28] Garanina, Z. G., Balyaev, S. I., \& Ionova, M. S. (2019). The Role of Self-Attitude in the Personal and Professional Development of High School Students. The Education and science journal, 21(1), 82-96. https://doi.org/10.17853/1994-5639-2019-1-82-96

[29] Garrison, D. R. (2011). E-learning in the 21st century: A framework for research and practice. London: Routledge.

[30] Georgouli, K., Skalkidis, I., \& Guerreiro, P. (2008). A framework for adopting LMS to introduce e-learning in a traditional course. Journal of Educational Technology \& Society, 11(2), 227-240.

[31] Gerasimova, V. G., Romanova, Y. D., \& Zhenova, N. A. (2018). Russian market of LMS for higher education. Astra Salvensis, 6, 757-767.

[32] Global Leadership Forecast-2018 (2018) DDI. Retrieved from: https://www.ddiworld.com/ DDI/media/trend-research/glf2018/global-leadership-forecast-2018_ddi_tr.pdf?ext=.pdf

[33] Gorbunovs, A., Timsans, Z., Zuga, B., \& Zagorskis, V. (2017). Conceptual design of the new generation adaptive learning management system. International Journal of Engineering \& Technology, 7(2.28), 129-133. https://doi.org/10.14419/ijet.v7i2.28.12894

[34] Gregori, P., Martínez, V., \& Moyano-Fernández, J. J. (2018). Basic actions to reduce dropout rates in distance learning. Evaluation and program planning, 66, 48-52. https:// doi.org/10.1016/j.evalprogplan.2017.10.004

[35] Griffiths, B. (2016). A Faculty's Approach to Distance Learning Standardization. Teaching and Learning in Nursing, 11(4), 157-162. https://doi.org/10.1016/j.teln.2016.04.004

[36] Heidrich, L., Barbosa, J. L. V., Cambruzzi, W., Rigo, S. J., Martins, M. G., \& dos Santos, R. B. S. (2018). Diagnosis of learner dropout based on learning styles for online distance learning. Telematics and Informatics, 35(6), 1593-1606. https://doi.org/10.1016/j.tele. 2018.04.007

[37] Honegger, M. (2020). What Does "Education" Mean: Cultural Values in Educational Language. Journal of Culture and Values in Education, 3(2), 42-53. https://doi.org/10. 46303/jcve.2020.12

[38] Huang, T. C., Lau, R., Huang, Y. M., Spaniol, M., \& Yuen, C. H. (2017). Emerging Technologies for Education Second International Symposium, SETE 2017, Held in Conjunction with ICWL 2017. Cape Town, South Africa. Cham: Springer. https://doi.org/10.1007/9783-319-71084-6

[39] Hung, M. L., Chou, C., Chen, C. H., \& Own, Z. Y. (2010). Learner readiness for online learning: Scale development and student perceptions. Computers \& Education, 55(3), 1080-1090. https://doi.org/10.1016/j.compedu.2010.05.004

[40] Jin, D., Chen, J., Richard, C., \& Chen, J. (2018). Model-driven online parameter adjustment for zero-attracting LMS. Signal Processing, 152, 373-383. https://doi.org/10.1016/ j.sigpro.2018.06.020

[41] Juhaňák, L., Zounek, J., \& Rohlíková, L. (2019). Using process mining to analyze students' quiz-taking behavior patterns in a learning management system. Computers in Human Behavior, 92, 496-506. https://doi.org/10.1016/j.chb.2017.12.015

[42] Koenen, A. K., Dochy, F., \& Berghmans, I. (2015). A phenomenographic analysis of the implementation of competence-based education in higher education. Teaching and Teacher Education, 50, 1-12. https://doi.org/10.1016/j.tate.2015.04.001

[43] Korableva, O., Durand, T., Kalimullina, O., \& Stepanova, I. (2019). Studying user satisfaction with the MOOC platform interfaces using the example of coursera and open education platforms. Paper presented at the ACM International Conference Proceeding Series, 26-30. https://doi.org/10.1145/3322134.3322139

[44] Krasnova, L.A. (2017). Development of teachers' information competency in higher education institution. Astra Salvensis, 5(10), 307-314. 
[45] Krausert, A. (2017). HR differentiation between professional and managerial employees: Broadening and integrating theoretical perspectives. Human Resource Management Review, 27(3), 442-457. https://doi.org/10.1016/j.hrmr.2016.11.002

[46] Law, K. M., Geng, S., \& Li, T. (2019). Student enrollment, motivation and learning performance in a blended learning environment: The mediating effects of social, teaching, and cognitive presence. Computers \& Education, 136, 1-12. https://doi.org/10.1016/j.compedu. 2019.02.021

[47] LearnDash. (2019). 20 Most Popular Learning Management Systems Available Today. Retrieved from: https://www.learndash.com/20-most-popular-learning-management-systemsinfographic/

[48] Lee, K., Choi, H., \& Cho, Y. H. (2019). Becoming a competent self: A developmental process of adult distance learning. The Internet and Higher Education, 41, 25-33. https:// doi.org/10.1016/j.iheduc.2018.12.001

[49] Leschinsky, A. (2016). Acmeological Approach in the Construction of Curriculum of Higher Education. Cherkasy University Bulletin: Pedagogical Sciences, 24(317).

[50] Lewis-Pierre, L., \& Aziza, K. (2017). Developing and implementing an interactive end-oflife education module using raptivity and ispring: lessons learned. Quarterly Review of Distance Education, 18(1), 9-15.

[51] Louwa, J., Brown, C., Muller, J., \& Soudien, C. (2009). Instructional technologies in social science instruction in South Africa. Computers \& Education, 53(2), 234-242. https://doi. org/10.1016/j.compedu.2009.02.001

[52] Lowell, V. L., \& Morris Jr, J. M. (2019). Multigenerational classrooms in higher education: equity and learning with technology. The International Journal of Information and Learning Technology, 36(2), 78-93. https://doi.org/10.1108/ijilt-06-2018-0068

[53] Maslova, I., Burdina, G., \& Krapotkina, I. (2020). The use of electronic educational resources and innovative educational technologies in university education. International Journal of Emerging Technologies in Learning, 15(16), 68-79. https://doi.org/10.3991/ijet. v15i16.14909

[54] MATRIX Blog. (2019). Generation $Z$ in the workplace. Retrieved from https://blog.matrixlms.com/generation-z-in-the-workplace/

[55] McKinsey \& Company. (2019). Generation Z characteristics and its implications for companies Retrieved from: https://www.mckinsey.com/industries/consumer-packagedgoods/our-insights/true-gen-generation-z-and-its-implications-for-companies

[56] Mishra, P., Koehler, M. J., \& Kereluik, K. (2009). Looking back to the future of educational technology. TechTrends, 53(5), 49.

[57] Modern distance learning platforms: wide choice, unlimited possibilities (2019). Modern platforms for distance learning: a wide choice, unlimited possibilities. Retrieved from: http://hrdocs.ru/poleznaya-informacziya/sovremennyie-platformyi-dlya-distanczionnogoobucheniya-shirokij-vyibor,-bezgranichnyie-vozmozhnosti/

[58] Mohr, K. A. (2017). Understanding Generation Z students to promote a contemporary learning environment. Journal on Empowering Teaching Excellence, 1(1), 9. doi: 10.15142/T3M05T

[59] Mubarak, Am., Al-Khatir, \& Al-Arimi (2014). Distance Learning. Procedia - Social and Behavioral Sciences, 152, 82-88. https://doi.org/10.1016/j.sbspro.2014.09.159

[60] Nabavi, R. T. (2012). Bandura's social learning theory \& social cognitive learning theory. Theory of Developmental Psychology (pp. 1-24). Retrieved from https://www.academia.edu/37627563/BandurasTheory.pdf 
[61] Pavlenko, L., \& Pushney, O. (2018). Study of the Prospects of Introducing Mixed Learning in Higher Education. Ukrainian Journal of Educational Studies and Information Technology, 6(1), 69-76. https://doi.org/10.32919/uesit.2018.01.10

[62] Palyanitsina, A. N., \& Akhmedova, A. N. (2020). Implementing the case study method in a process of teaching oil engineers. Paper presented at the Journal of Physics: Conference Series, 1515(2) https://doi.org/10.1088/1742-6596/1515/2/022049

[63] People Matters Interstitial Site People Matters (2019). Retrieved from: https://www.peoplematters.in/article/learning-management-systems/the-story-on-learningmanagement-system-14889?utm_source=peoplematters\&utm_medium=interstitial\&utm campaign=learnings-of-the-day. https://doi.org/10.3403/30383262u

[64] Phelps, C., \& Michea, Y. (2015). Learning Management Systems' Evaluation Focuses on Technology Not Learning. Retrieved from: https://www.ncbi.nlm.nih.gov/pmc/articles/ PMC1480024/

[65] Priatna, T., Maylawati, D. S., Sugilar, H., \& Ramdhani, M. A. (2020). Key success factors of e-learning implementation in higher education. International Journal of Emerging Technologies in Learning, 15(17), 101-114. https://doi.org/10.3991/ijet.v15i17.14293

[66] Rachel, V., \& Parthasarathy, M. (2016). Learning management system using open source moodle for computer science students in higher educational institute. International Journal of Computer Science \& Engineering Technology (IJCSET), 7(1), 13-18.

[67] Rumble, G. (2019). The planning and management of distance education. London: Routledge.

[68] Rüth, M., \& Kaspar, K. (2017). The E-Learning Setting Circle: First Steps toward Theory Development in E-Learning Research. Electronic Journal of e-Learning, 15(1), 94-103.

[69] Samedov M.N.O., Aikashev G.S., Deryagin A.V., \& Sahabiev I.A. (2015). A study of socialization of children and student-age youth by the express diagnostics methods. Biosciences Biotechnology Research Asia, 12(3), 2711-2722. https://doi.org/10.13005/bbra/1953

[70] Shortsleeve, Al. (2019). Learning Management Systems: what they are, and why you might want one. Retrieved from: https://medium.freecodecamp.org/learning-managementsystems-what-they-are-and-why-you-might-want-one-9bc28186e395.

https://doi.org/10.1136/

bmj.j76

[71] Shurygin, V.Y., \& Krasnova, L.A. (2020). Blended learning of physics in the context of the professional development of teachers. International Journal of Technology Enhanced Learning, 12(1), 38-52. https://doi.org/10.1504/ijtel.2020.103814

[72] Simkova, M., \& Stepanek, J. (2013). Effective use of virtual learning environment and LMS. Procedia-Social and Behavioral Sciences, 83, 497-500. https://doi.org/10.1016/ j.sbspro.2013.06.096

[73] Soykan, F., \& Şimşek, B. (2017). Examining studies on learning management systems in SSCI database: A content analysis study. Procedia computer science, 120, 871-876. https:// doi.org/10.1016/j.procs.2017.11.320

[74] Sun, P. C., Tsai, R. J., Finger, G., Chen, Y. Y., \& Yeh, D. (2008). What drives a successful e-Learning? An empirical investigation of the critical factors influencing learner satisfaction. Computers \& education, 50(4), 1183-1202. https://doi.org/10.1016/j.compedu.20 06.11 .007

[75] TalentLMS. (2019). What is an LMS? Definition and Uses for Business \& Education in 2019. Retrieved from https://www.talentlms.com/what-is-an-lms

[76] Touimi, Y. B., Hadioui, A., Faddouli, N. E., \& Bennani, S. (2020). Intelligent chatbotLDA recommender system. International Journal of Emerging Technologies in Learning, 15(20), 4-20. https://doi.org/10.3991/ijet.v15i20.15657 
[77] The History of LMS and the Future of Learning. Cornerstone. (2019). The History of LMS and the Future of Learning. Cornerstone. Retrieved from: https://www.cornerstoneonde mand.com/resources/articles/what-history-learning-management-system-teaches-us-aboutfuture-learning

[78] THE Journal. (2019). E-Learning \& LMS. Retrieved from https://thejournal.com/articles/ list/elearning.aspx

[79] Tarman, B. (2020). Editorial: Reflecting in the shade of pandemic. Research in Social Sciences and Technology, 5(2), i-iv. https://doi.org/10.46303/ressat.05.02.ed

[80] Turnbull, D., Chugh, R., \& Luck, J. (2019). Learning Management Systems: An Overview (pp. 1-7). Encyclopedia of Education and Information Technologies. Cham: Springer.

[81] Utemov, V. V., Khusainova, R. M., Sergeeva, M. G., \& Shestak, V. A. (2018). Full Packaged Learning Solutions for Studying Mathematics at School. EURASIA Journal of Mathematics, Science and Technology Education, 14(12), 1-13. https://doi.org/10.29333/ejmste/ $\underline{95122}$

[82] Wang, C., Hsu, H. C. K., Bonem, E. M., Moss, J. D., Yu, S., Nelson, D. B., \& LevesqueBristol, C. (2019). Need satisfaction and need dissatisfaction: A comparative study of online and face-to-face learning contexts. Computers in Human Behavior, 95, 114-125. https://doi.org/10.1016/j.chb.2019.01.034

[83] You, J. W. (2016). Identifying significant indicators using LMS data to predict course achievement in online learning. The Internet and Higher Education, 29, 23-30. https://doi. org/10.1016/j.iheduc.2015.11.003

[84] Your Digital Learning Expert. (2019). What is an LMS in 2019? How to Launch eLearning with an LMS. Retrieved from: https://www.ispringsolutions.com/blog/what-is-lms

[85] Yu, C., Lee, S. J., Yu, W. C. W., \& Walton, A. L. (2018). Exploring Issues and Challenges of Project-Based Learning for Teaching and Learning. In Handbook of Research on Pedagogical Models for Next-Generation Teaching and Learning (pp. 98-117). IGI Global. https://doi.org/10.4018/978-1-5225-3873-8.ch006

[86] Zakharova, I. G. (2018). Machine Learning Methods of Providing Informational Management Support for Students' Professional Development. The Education and science journal, 20(9), 91-114. https://doi.org/10.17853/1994-5639-2018-9-91-114

[87] Zhang, Y., Ghandour, A., \& Shestak, V. (2020). Using learning analytics to predict students performance in moodle LMS. International Journal of Emerging Technologies in Learning, 15(20), 102-114. https://doi.org/10.3991/ijet.v15i20.15915

[88] Zapier. (2019). The Best LMS Software: 8 Learning Management Systems to Train Your Employees. Retrieved from https://zapier.com/blog/best-lms/

[89] Zhu, R., Dong, M., \& Xue, J. H. (2019). Learning distance to subspace for the nearest subspace methods in high-dimensional data classification. Information Sciences, 481, 69-80. https://doi.org/10.1016/j.ins.2018.12.061

\section{Authors}

Viktor Shurygin has $\mathrm{PhD}$ in physics and mathematics. He is an Associate Professor at Kazan Federal University, Elabuga Institute (Branch), Elabuga, Russia. In recent years, the area of his scientific interests is the study of various aspects of distance and blended physics education.

Natalya Saenko, candidate of Philological Sciences (1999), Doctor of Philosophy (2012), Professor of Moscow Polytechnic University. Saenko Natalya is engaged in 
the philosophy of modern culture, the theory, and the history of conceptualism, semiotics, and hermeneutics of a literary text.

Angelina Zekiy, Doctor of Medical Science, Professor of Department of Prosthetic Dentistry, E.V. Borovsky Institute of Dentistry. Author specializes in the study and implementation of digital dentistry in universities.

Elena Klochko, Doctor of Economic Sciences, Professor of Department of Management, Kuban State Agrarian University named after I.T. Trubilin. Author specializes in the study of virtual and digital processes in economic systems, the study of the hidden possibilities of the ethnic economy.

Mikhail Kulapov, Doctor of Economics, Professor, Head of the Scientific School "Management Theory and Technologies". Laureate of the Prize of the Government of the Russian Federation in the field of education for 2005 "For the educational and methodological kit for educational institutions of higher professional education and vocational education in the specialty" Labor Economics ", Honored Worker of Higher School of the Russian Federation.

Article submitted 2020-12-22. Resubmitted 2021-01-28. Final acceptance 2021-01-28. Final version published as submitted by the authors. 